\title{
Kultura regionu - inspiracje i kierunki rozwoju edukacji regionalnej we współczesnej szkole
}

\begin{abstract}
Streszczenie
W tekście podejmujemy próbę pokazania syntezy współczesnego rozumienia edukacji regionalnej, uwzględniając także podstawy prawne niniejszego zagadnienia. Zwracamy uwagę na możliwości realizacji treści regionalnych w praktyce edukacyjnej. Przedstawiamy wybrane kreatywne metody i formy wykorzystywane w edukacji regionalnej. Odnosimy się również do wyzwań stojących przed wspomnianą edukacją realizowaną w obszarze pedagogiki miejsca. Celem pracy było wskazanie kierunków rozwoju edukacji regionalnej we współczesnej szkole oraz pokazanie interesujących obszarów w kulturze regionu, z których może ona czerpać inspiracje. Przyczynkiem do poznania i analizy omawianego problemu w przestrzeni nauki były studia literatury i analizy badań naukowych ukazujące rolę edukacji regionalnej w budowaniu „ojczyzny prywatnej”, kształtowania identyfikacji z miejscem zamieszkania, a także zagadnień związanych z pamięcią regionalną, pamięcią społeczną, dziedzictwem kulturowym, regionem. Ponadto impulsem do podjęcia tego tematu były osobiste refleksje dotyczące przekazywania znaczenia edukacji regionalnej i jej roli w kształtowaniu tożsamości miejsca - tożsamości regionu.
\end{abstract}

1 Joanna Sacharczuk, Wydział Pedagogiki i Psychologii, Uniwersytet w Białymstoku, Polska, e-mail: joannasacharczuk@tlen.pl, ORCID ID: https://orcid.org/0000-0001-6031-1167.

2 Alina Szwarc, Wydział Pedagogiki i Psychologii, Uniwersytet w Białymstoku, Polska, e-mail: a.szwarc@uwb.edu.pl, ORCID ID: https://orcid.org/0000-0002-3075-5872. 


\title{
Słowa kluczowe:
}

edukacja regionalna, pedagogika miejsca, pamięć społeczna, region, formy organizacyjne kształcenia, metody kształcenia

\begin{abstract}
In the text, we attempt to show the synthesis of contemporary understanding of regional education, also taking into consideration the legal basis of this issue. We pay attention to the possibility of implementing regional content in educational practice. We present selected creative methods and forms that are used in regional education. We also refer to the challenges facing regional education implemented in the area of pedagogy of the place. The aim of the work was to indicate the directions of development of regional education in a modern school and to show interesting areas in the culture of the region from which it can draw inspiration. The basis for learning and analyzing the problem of regional education in the space of science were literature studies and analyzes of scientific research. This procedures allow us to show the role of regional education in building a "private homeland", shaping the identification with the place of residence, as well as issues related to regional memory, social memory, cultural heritage, region. Another impulse to take up this topic was our personal reflections on the transfer of the importance of regional education and its role in shaping the identity of the place - the identity of the region.
\end{abstract}

\section{Keywords:}

regional education, pedagogy of the place, social memory, region, organizational forms of education, methods of education

W tekście podejmujemy próbę pokazania syntezy współczesnego rozumienia edukacji regionalnej, uwzględniając także podstawy prawne niniejszego zagadnienia. Zwracamy uwagę na możliwości realizacji treści regionalnych w praktyce edukacyjnej. Przedstawiamy wybrane kreatywne metody i formy wykorzystywane w tego typu edukacji. Odnosimy się również do wyzwań stojących przed edukacją regionalną realizowaną w obszarze pedagogiki miejsca. Celem pracy było wskazanie kierunków rozwoju edukacji regionalnej we współczesnej szkole oraz pokazanie interesujących obszarów w kulturze regionu, z których może ona czerpać inspiracje. 


\section{EDUKACJA REGIONALNA - UJĘCIE TEORETYCZNE}

\subsection{ZAŁOŻENIA EDUKACJI REGIONALNEJ}

Piotr Petrykowski wskazuje na rolę edukacji regionalnej w rekonstruowaniu przeszłości konkretnego regionu w ramach odniesień istotnych dla teraźniejszości Pisze, że edukacja regionalna jest to: „(...) umożliwianie młodym ludziom poznawania własnego dziedzictwa kulturowego, tradycji regionalnej, uwewnętrznienia wartości i treści regionalnych, tym samym więc kształtowanie i utrwalanie postaw regionalnych” (Petrykowski, 2003, s. 50). Edukacja regionalna jest ściśle powiązana z edukacją międzykulturową, jest w pewnym sensie jej pierwszym etapem, niezbędnym warunkiem powodzenia zamierzeń wynikających z teoretycznych założeń edukacji międzykulturowej. Na co zwraca uwagę między innymi Jerzy Nikitorowicz. W toku zapoznawania dzieci i młodzież z kulturą lokalną „rozpoczyna proces dialogu edukacyjnego, wzmacnia ich siły poprzez poznanie i zrozumienie siebie oraz swojej najbliższej kultury. W efekcie pozwala dostrzegać odmienności oraz poszukiwać sposobów wzajemnego zrozumienia, porozumienia i współpracy" (Nikitorowicz, 2017, s. 130). Edukacja regionalna to edukacja środowiskowa, wiedza o ojczyźnie lokalnej, prywatnej. Pełni bardzo ważną rolę w kreowaniu tożsamości członka społeczeństwa obywatelskiego. Znaczącym czynnikiem efektywności komunikacji w realizacji edukacji regionalnej jest:

znajomość dziedzictwa kulturowego, świadomość własnej specyfiki, procesów wymiany, ciągłych przeobrażeń. Wychowawca, kształtując u dziecka poczucie własnej tożsamości, zobowiązany jest budować jednocześnie fundament pod jego postawy otwarte i tolerancyjne, które będą mogły kreować pluralizm kulturowy. Ważne jest, aby zauważał i godził postawy regionalizmu i uniwersalizmu, aby pomagał w przyswajaniu nowej kultury, nowego środowiska, języka, sposobów komunikowania się, adaptowania do inności, nie odrzucając wartości rodzinno-familijnych. Taka działalność pozwoli dziecku na nabycie zdolności do rozpoznawania i nazywania własnych odczuć, kierowania własnymi emocjami, dostrzegania uczuć innych oraz nawiązywania i podtrzymywania kontaktów społecznych (Nikitorowicz, 2017, s. 134).

Mirosław Sobecki zwraca uwagę na to, że dzięki regionowi i jego kulturze, mogą przetrwać wartości rdzenne. Zdaniem autora istotne jest jednak to, że „(...) w małej ojczyźnie doświadczamy pierwszych kontaktów z odmiennością. Stąd edukacja regionalna wychodzi naprzeciw człowiekowi, kształtując tak umiejętność 
współżycia z innymi, jak i służebnego zaangażowania w przetrwanie mikroświata małej ojczyzny” (Sobecki, 2007, s. 138).

Barbara Synak uważa, iż celem edukacji regionalnej jest kształtowanie poczucia własnej tożsamości lokalnej i regionalnej, a jej funkcje to:

- kształtowanie poczucia grupowej tożsamości,

- uczenie tolerancji wobec innych społeczności,

- integracja ludności pochodzących z różnych regionów,

- przygotowanie do życia w ojczyźnie narodowej, kształtowanie patriotyzmu lokalnego i narodowego,

- kształtowanie społeczeństwa obywatelskiego i ładu demokratycznego,

- rozwijanie poczucia odpowiedzialności za małą i wielką ojczyznę,

- kształtowanie współodpowiedzialności za innych (Synak, 2000).

Marek Stanisław Szczepański w swoich pracach wyraźnie akcentuje, iż oferta treści regionalnych powinna być skierowana przede wszystkim do młodego pokolenia. Zauważa, iż w rozwoju dzieci i młodzieży bardzo ważną rolę odgrywa właśnie taka edukacja, głównie z uwagi na procesy poznawcze i emocjonalne (Szczepański, 1999). Autor jako jeden z pierwszych zaproponował formy realizacji edukacji regionalnej w szkole, natomiast wśród treści realizowanych w jej ramach wyróżnił następujące zagadnienia:

- elementy mikroekologii i mikrogeografii,

- historia regionalna (dotycząca wiedzy o lokalnych wydarzeniach, postaciach, polityce),

- wiedza socjologiczna, dotycząca społeczności lokalnych, krain kulturowych, zmian cywilizacyjnych w regionie),

- wiedza o lokalnej gwarze i literaturze,

- wiedza o kulturze materialnej, twórczości artystycznej i rzemieślniczej (Szczepański, 1995).

Przesłanki i cele edukacji regionalnej - wyposażenie uczniów w wiadomości z zakresu problematyki regionu, którego są mieszkańcami, zaliczyć można do podstawowych zaleceń pedagogiki i teorii poznania. Wskazane cele i zadania mają pozwolić na możliwie najpełniejsze uczestnictwo w życiu społeczności, co wiąże się z poznawaniem i przekazywaniem swoistych wartości dla dobra zarówno człowieka jako jednostki, jak i cywilizacji ludzkiej (Treder, 1999).

Edukacja regionalna, jako koncepcja podkreślająca „(...) dydaktyczne znaczenie lokalnego dziedzictwa kulturowego, jako niezbędnego elementu tożsamości jednostkowej i społecznej, stanowi ważny składnik procesu integracji europejskiej; sprzyja zakorzenieniu w tzw. małej ojczyźnie” (Milerski, Śliwerski 2000, 
s. 56), pełni istotną rolę w pielęgnowaniu pamięci społecznej. Z perspektywy edukacji regionalnej ważnym czynnikiem analiz jest przeszłość wspólnot lokalnych, o czym pisał Lech Witkowski:

\begin{abstract}
(...) jeśli postulat reprezentujący rozumienie funkcji (edukacji) przygotowania do twórczego uczestnictwa w kulturze ma mieć zasięg uniwersalny, to oswajanie z kulturą własnego „środowiska” - zakreślonego promieniem interakcji opartej na wspólnocie światopoglądowej, etnicznej czy zupełnie lokalnej - nie może dokonywać się bez troski o dopuszczenie do głosu słowa „nie z tego świata”. Treści cudzych przeżyć i postaw to dane, które (stanowiąc osnowę świata nam obcego) dzięki redukcji dzielącego nas wzajemnie dystansu zarazem lepiej oświetlą nam nasz własny świat i ustanowią stosunki pogranicza ze światem cudzym, stosunki wzbogacające życie w każdym z tych światów (Witkowski, 1997, s. 74-75).
\end{abstract}

Zadaniem edukacji regionalnej jest poszerzanie przestrzeni środowiska życia jednostek o miejsca należące do obiektywnego i szerszego środowiska oraz włączanie ich do środowiska subiektywnego. Celem edukacji regionalnej jest pokazywanie i uświadamianie wartości środowiska obiektywnego, w tym miejsc społecznie ważnych, oraz ułatwianie subiektywizowania ich.

Przeszłość regionalna (Szpociński, Kwiatkowski, 2006, s. 82-83) jest osnową edukacji regionalnej, składają się na nią wydarzenia, które miały miejsce na terytorium zwanym regionem, a której podmiotem była cała zamieszkująca go zbiorowość - wchodzące w jej skład mniejsze grupy. Na przeszłość regionu składają się liczne przeszłości różnych grup społecznych, niezależnie od siebie symbolizowane i pamiętane. Przeszłość mniejszości może być włączona do tradycji regionalnej na dwa sposoby. Po pierwsze, dzieje tej grupy mogą wchodzić do tradycji regionalnej jako całość, to znaczy całemu okresowi istnienia tej grupy przypisuje się określoną wartość, ważną dla całej zbiorowości. Drugim sposobem jest dopełnianie obrazu przeszłości regionalnej wybranymi faktami z dziejów owej grupy mniejszościowej.

Jednym z zadań edukacji regionalnej jest pokazywanie potencjału, jakim dysponuje społeczeństwo i uwrażliwiane na odmienność różnych grup etnicznych i kulturowych zamieszkujących to samo terytorium. Edukacja regionalna jest konieczna szczególnie w miejscach, które członkowie różnych grup kulturowych odziedziczyli po swoich przodkach, co daje im prawo do poczucia „bycia u siebie”. Stąd też istota edukacji regionalnej oscyluje wokół problemu dziedzictwa kulturowego. Pamięć społeczna warunkuje przekaz elementów kultury regionu, 


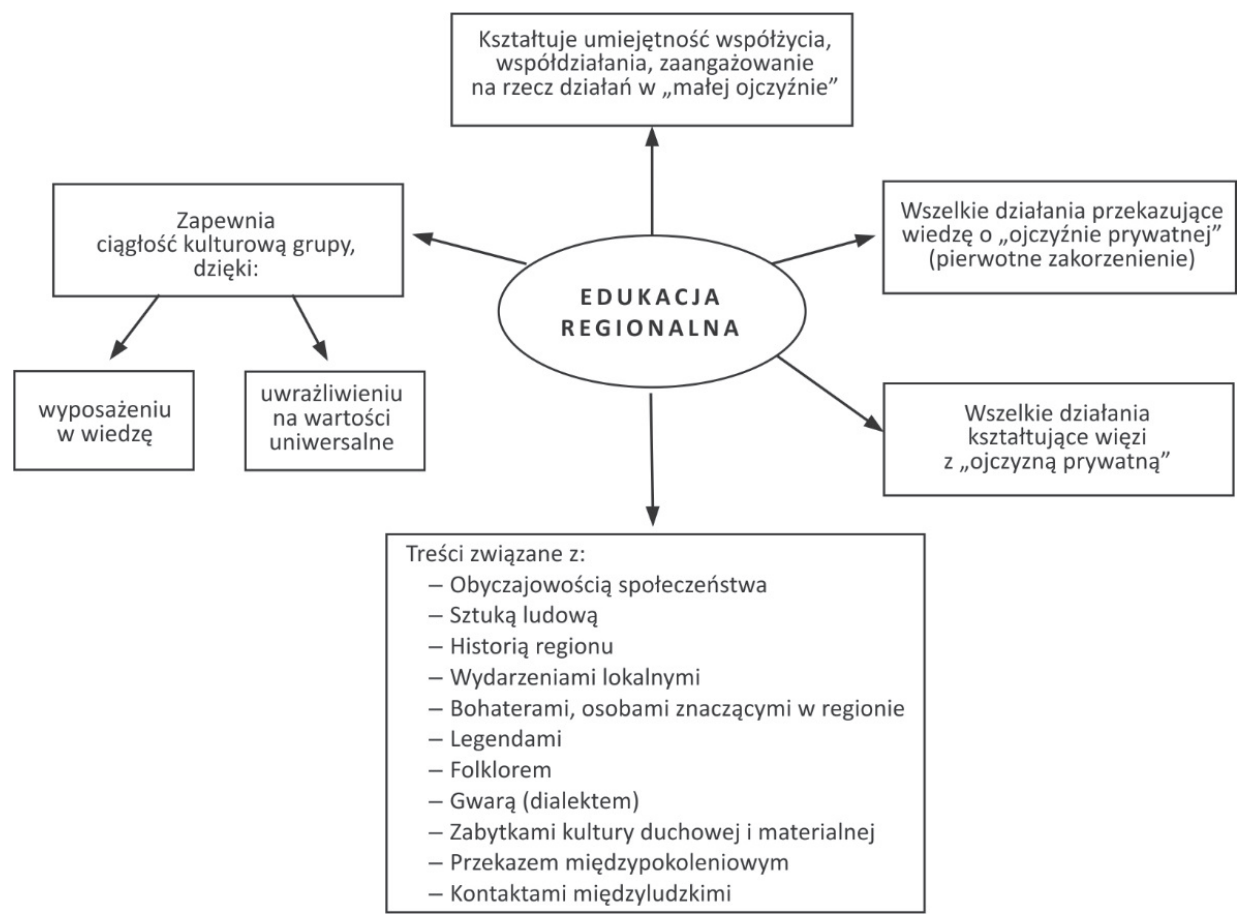

Mapa 1. Edukacja regionalna

Źródło: opracowanie własne (na podstawie Petrykowski, 2003; Nikitorowicz, 2009).

nadając tym samym zaznaczenie dziedzictwu kulturowemu, które, jak pokazuje P. Petrykowski, „(...) w kontekście rozważań nad czynnikami konstytuującymi tożsamość kulturową i tożsamość regionalną jest składową wyznaczników regionu” (Petrykowski, 2003, s. 128).

\subsection{PODSTAWY PRAWNE W REALIZACJI EDUKACJI REGIONALNEJ}

W 1995 roku Ministerstwo Edukacji Narodowej skierowało do szkół opracowanie Dziedzictwo kulturowe w regionie. Założenia programowe, które stało się jednym z pierwszych dokumentów regulujących realizację edukacji regionalnej. Do głównych jej celów zaliczono m.in.: pełniejsze poznanie własnej kultury i dziedzictwa kulturowego, wydobycie wartości własnego regionu w kontekście wartości narodowych, państwowych, ale i ogólnoludzkich, kształtowanie świadomych praw obywateli kraju i swojej „małej ojczyzny” oraz kształtowaniu postaw otwartych, umożliwiających poznanie innych kultur i zbliżenie europejskie (Dziedzictwo kulturowe w regionie. Założenia programowe,1995). 
W 2000 roku z serii Biblioteczka Reformy ukazuje się kolejny dokument: Ministerstwo Edukacji Narodowej o edukacji regionalnej - dziedzictwie kulturowym $w$ regionie, w którym proponuje się nauczycielom, by podjęli się autorskiego tworzenia programu kształcąco-wychowawczego z zakresu tej problematyki. W edukacji regionalnej „(...) nie da się (tak jak np. w matematyce) wprowadzić rozwiązań identycznych w szkołach całej Polski. Inne są bowiem doświadczenia Kaszubów, inne Mazurów (...) i tę specyfikę trzeba uwzględnić” (Ministerstwo Edukacji Narodowej o edukacji regionalnej-dziedzictwie kulturowym w regionie, 2000, s. 5).

Podstawowym dokumentem określającym treści realizowane w szkole jest podstawa programowa. W obowiązującej podstawie programowej kształcenia ogólnego, ale i w poprzednich jej wersjach, odnaleźć można wiele nawiązań do problematyki regionalnej. Już w pierwszej podstawie programowej z 1999 roku zaznacza się, iż ważne jest „uczenie szacunku dla dobra wspólnego jako podstawy życia społecznego oraz przygotowywanie się do życia w rodzinie, w społeczności lokalnej i w państwie w duchu przekazu dziedzictwa kulturowego i kształtowania postaw patriotycznych” (Rozporządzenie Ministra Edukacji Narodowej z dnia 15 lutego 1999 r. w sprawie podstawy programowej kształcenia ogólnego (Dz.U.1999.14.129)). W wszystkich podstawach od pierwszych etapów edukacyjnych pisze się o konieczności kształtowania poczucia przynależności do społeczności szkolnej, środowiska lokalnego, regionu i kraju, realizacji treści dotyczących podobieństwa i różnic między ludźmi, zrozumienia i tolerancji, jak również różnorodności dziedzictwa i poszukiwań w sferze kultury. Zgodnie z obecnymi przepisami treści regionalne realizowane są w ramach poszczególnych przedmiotów szkolnych. Z perspektywy dydaktycznej wydaje się jednak, iż korzystnym rozwiązaniem w nauczaniu treści regionalnych były tzw. ścieżki edukacyjne: „Wychowanie do życia w społeczeństwie”, a w jej ramach „Wychowanie regionalne - dziedzictwo kulturowe w regionie”. Za ich realizację odpowiedzialni byli nauczyciele wszystkich przedmiotów, którzy do własnego programu włączali odpowiednio treści danej ścieżki. Nauczyciele mogli również organizować odrębne, modułowe, kilkugodzinne zajęcia, które stanowiły doskonałą okazję do poznawania kultury regionu podczas różnorodnych spotkań, wycieczek, kół zainteresowań, projektów międzyprzedmiotowych. W wielu szkołach, m.in. na terenie Podlasia, takie ścieżki realizowane były na wysokim poziomie, ale przede wszystkim odbywały się w sposób interesujący i angażujący uczniów w poznawanie treści regionalnych (Szwarc, 2011, s. 188-199). Niestety od 2009 roku podstawy programowe nie uwzględniają już ścieżek międzypodmiotowych. 


\section{KREATYWNA PRAKTYKA - MOŻLIWOŚCI REALIZACJI TREŚCI REGIONALNYCH W PRAKTYCE EDUKACYJNEJ}

\subsection{FORMY ORGANIZACYJNE KSZTAŁCENIA - ZAJĘCIA POZALEKCYJNE I POZASZKOLNE}

Specyfika zajęć pozalekcyjnych i pozaszkolnych wynika z faktu, iż wiążą się z czasem wolnym i indywidualnymi zainteresowaniami uczniów. W praktyce szkolnej wiele takich zajęć jest marginalizowanych, a ich funkcje i cele nie zawsze właściwie realizowane. Efektywna realizacja tego typu zajęć wiąże się z następującymi wymaganiami:

- powinny uwzględniać zmianę treści i sam charakter działań, jaki wynika ze szkolnych zajęć obowiązkowych,

- zmiany wymaga również otoczenie społeczne ucznia - nie powinno ograniczać się do klasy szkolnej i formalnej jej organizacji,

- zmiany otoczenia materialnego - miejscem takich zajęć nie powinna być klasa szkolna (Żelazkiewicz, 1980).

Zajęcia pozalekcyjne są przede wszystkim bardzo ważnym elementem systemu dydaktyczno-wychowawczego szkoły, a ich formy i treści często są efektem zmian społecznych, gospodarczych i politycznych, ale i rozwoju nauki i techniki. Współczesne zajęcia pozalekcyjne często odbywają się poza terenem szkoły, stąd wiele ich przykładów może pełnić jednocześnie funkcje zajęć pozalekcyjnych i pozaszkolnych lub pozalekcyjnych i szkolnych. Niezależnie od przyjętej klasyfikacji czasu i miejsca mogą one stanowić doskonałą okazję do zarówno poznania, jak i promowania swojej małej ojczyzny, ale i zapoznania uczniów z kulturą innych regionów polski, jak i innych krajów. W praktyce edukacyjnej dużą popularnością cieszą się koła regionalne, turystyczno-krajoznawcze, geograficzne, regionalno-historyczne. Cele pracy z uczniem podczas tego typu zajęć nastawione są na kształtowanie więzi emocjonalnych z miejscem zamieszkania, nawiązanie więzi ze środowiskiem lokalnym. Ważne jest kształtowanie wiedzy o kulturze i historii własnego regionu, ale też pokazywanie związku z kulturą narodową, pielęgnowanie tożsamości regionalnej i narodowej, przybliżanie tradycji regionu, nawiązanie kontaktu z miejscowymi twórcami i zabytkami. Również istotnym celem jest wskazanie przykładów umożliwiających integrację z kulturą narodu. Ważnym kierunkiem działań edukacyjnych jest pobudzenie społecznej aktywności i odpowiedzialności za rozwój ojczyzny prywatnej, ale i kształtowanie postaw tolerancji wobec członków innych grup etnicznych i kulturowych. 
Powyższe założenia mogą być realizowane również podczas spotkań w ramach kół europejskich, ale i różnego rodzaju pozalekcyjnych zajęć artystycznych, takich jak: muzyczne, plastyczne, teatralne. Do przykładów zajęć pozalekcyjnych, sprzyjających promocji treści regionalnych, należą również koła językowe, ale i samorząd uczniowski czy szkolne harcerstwo.

Innym przykładem zajęć pozalekcyjnych, w ramach których doskonale mogą funkcjonować np. koła zainteresowań, warsztaty, konkursy i inne zajęcia jest świetlica szkolna. Praca w świetlicy wyznaczona jest przez roczny plan pracy świetlicy i tygodniowe hasła tematyczne, a zajęcia w nich prowadzą osoby z przygotowaniem pedagogicznym do pracy z dziećmi i młodzieżą. Zgodnie z obecnymi przepisami szkoła zobowiązana jest na wniosek rodziców zapewnić zajęcia świetlicowe dla uczniów, którzy pozostają w niej dłużej ze względu na czas pracy opiekunów lub w przypadkach, gdy organizacja dojazdu do szkoły lub inne okoliczności wymagają zapewnienia opieki w szkole. Współcześnie świetlica stanowi wewnątrzszkolną instytucję opieki i wychowania, a jej główny cel to wspomaganie i uzupełnianie pracy szkoły w następujących jej zakresach:

1. Opieki - zaspokajanie podstawowych potrzeb dzieci, takich jak: bezpieczeństwo, akceptacja, radość oraz zapewnienie warunków sprzyjających zdrowiu i prawidłowemu rozwojowi.

2. Wychowania - kształtowanie osobowości, troska o dobre relacje (aby dzieci mogły zbierać pozytywne doświadczenia społeczne mające znaczący wpływ na ich rówieśnicze funkcjonowanie).

3. Dydaktyki - polega na wspomaganiu dydaktycznych zadań szkoły (poszerzanie wiedzy uczniów, kształtowanie różnego rodzaju umiejętności).

4. Oddziaływań profilaktyczno-terapeutycznych - zapobieganie utrwalaniu nieprawidłowych wzorców, a w stosunku do pewnej grupy wspomagają budowanie prawidłowych procesów (Pery, Kmita, 2014).

Zajęcia świetlicowe od wielu lat budzą kontrowersje, często zarzuca się im, iż pełnią funkcje „przechowalni”. Wyniki kontroli NIK wskazują, iż uczniowie w świetlicy spędzają aż trzy godziny dziennie, a dominującymi kryteriami tworzenia grup wychowawczych były przede wszystkim godziny rozpoczęcia i zakończenia lekcji. Ponadto ustalono, iż tylko w kilku kontrolowanych szkołach zaplanowano i zrealizowano zajęcia w grupach wychowawczych dla uczniów o wcześniej ustalonych potrzebach edukacyjnych i zainteresowaniach. Natomiast w większości kontrolowanych szkół brakowało systemowych działań dotyczących rozpoznawania potrzeb edukacyjnych i zainteresowań uczniów, w oparciu o które można by organizować grupy wychowawcze oraz prowadzić zajęcia w świetlicy (Najwyższa Izba Kontroli, 2017). 
Wśród zajęć pozaszkolnych, w przypadku realizacji treści o charakterze regionalnym, na szczególną uwagę zasługuje wycieczka. Już Ignacy Janowski pisał, iż wycieczki to „swoisty fenomen szkoły, źródło przeżyć i doświadczeń dla wszystkich osób podmiotowo zaangażowanych w teatr życia szkolnego. Z tego punktu widzenia można dostrzec w wycieczce tę szczególną jej właściwość, której nie ma w żadnej innej formie i metodzie kształcenia” (Janowski, 2002, s. 7). Wycieczka należy do niezwykle efektywnych form organizacyjnych, ale i najbardziej lubianych przez dzieci i młodzież. Głównym celem wycieczek jest zaznajamianie uczniów z określonymi treściami, często w ich naturalnym środowisku. Przedmiotem poznania tej formy organizacyjnej są zjawiska i procesy przyrodnicze, techniczne, społeczne i kulturowe. Jednak jej skuteczność jest uzależniona od czynności przygotowawczych, zwłaszcza określenia zadań i celów. Pełni ponadto ważne funkcje wychowawcze, zwłaszcza związane z procesem poznania ucznia czy integracji grupowej i umacnianiu więzi pomiędzy uczniami i nauczycielami (Denek, 2011; 1997; Kupisiewicz, 2002).

\subsection{METODA PROJEKTU JAKO PRZYKŁAD INNOWACJI W EDUKACJI REGIONALNEJ}

Zagadnienie innowacyjności i kreatywności w odniesieniu do metod kształcenia podejmuje A. Sajdak, twierdząc, iż same metody i techniki pracy stanowią najczęstszy przedmiot „(...) tak zwanych opisów z drugiej ręki, istniejąca literatura na ten temat jest zatem dość bogata i osoba zainteresowana bez trudu dotrze do źródeł, korzystając na przykład ze wskazówek bibliograficznych” (Sajdak, 2008, s. 195). Jednak w przypadku realizacji kreatywnej edukacji regionalnej zastosowanie niektórych metod może stać się źródłem wykorzystanych treści, stąd takim metodom warto bliżej się przyjrzeć. W teorii i praktyce edukacyjne istnieje wiele klasyfikacji i ujęć metod i technik kształcenia (Kruszewski, 2007, Niemierko, 2007; Okoń, 2003).Wśród metod aktywizujących na szczególną uwagę - w przypadku podjętego tematu - zasługuje metoda projektu, chociażby z uwagi, iż wymaga i zapewnia uczącemu się znacznie wyższy stopień autonomii niż inne metody. Uczy odpowiedzialności za własny proces kształcenia, podkreśla zasady i dyscyplinę pracy badawczej, jest znakomitym modelem samokształcenia. Mirosław Stanisław Szymański określa projekt jako metodę, której główną cechę stanowi to, że zespół osób uczących się samodzielnie ją inicjuje, planuje i wykonuje pewne przedsięwzięcie oraz ocenia jego wykonanie. Zdaniem autora źródłem projektu powinien być świat życia codziennego uczniów, a nie abstrakcyjna nauka. Stąd do cech charakterystycznych metody projektu zalicza: 
- interdyscyplinarność (wykonanie zadania projektowego wymaga od uczniów samodzielnego opanowania wiedzy z zakresu wielu przedmiotów nauczania, doskonale łączy pracę szkolną i działalność pozaszkolną),

- progresywistyczna rola nauczyciela (nauczyciel pełni rolę przewodnika i doradcy sterującego procesami grupowymi, pomaga uczniom, udziela wskazówek i wyjaśnień, jeśli potrzebują ich uczniowie),

- całościowość (rozumiana jako umiejscowienie projektu w kontekście pozaszkolnym, lokalnym lub globalnym; umożliwia wykorzystanie szerszego niż podczas tradycyjnej lekcji spojrzenia na omawiane zagadnienie, ale i dostrzeganie związków pomiędzy tym, czego uczą się uczniowie w szkole i poza nią, łączenie teorii z praktyką),

- odejście od tradycyjnego oceniania (przedmiotem oceny w metodzie projektu jest nie tyle efekt końcowy, ile jakość działania uczniów w trakcie wspólnego działania); bardzo ważne jest, by dokładnie opracować kryteria oceny poszczególnych etapów pracy i rodzajów aktywności uczniów; istotnym elementem oceniania jest samoocena i wzajemna ocena uczniów (Szymański, 2010).

Warto zwrócić uwagę na jeszcze inne walory metody projektu, o których pisze Krystyna Chałas, a do których zalicza udział uczniów w wyborze tematów projektów i wykorzystanych treści edukacyjnych, uczenie podejmowania decyzji co do wykonania zadań o znacznej trudności, kształtowanie umiejętności określania wspólnych celów pracy, wybór metod i form realizacji projektu przez uczniów oraz opracowanie przez nich wyników rozwiązywanego problemu, prezentacja własnych osiągnięć, jak i współudział w ocenienie wykonanego projektu (Chałas, 2004; 2000). Podczas pracy metodą projektu uczniowie generują konkretne produkty, które często wykraczają poza poszczególne dyscypliny. Pozwala to skoncentrować się na stosowaniu wiedzy w praktyce i działaniu. Bardzo ważny cel metody projektu to podniesienie wewnętrznej motywacji i własnej wartości, twórczego i niezależnego myślenia, jak i odpowiedzialności społecznej (Nawój-Połoczańska, 2018).

Cechy postępowania metodycznego w metodzie projektu według Johna A. Stevensona:

- Nabywanie wiedzy powinno zachodzić głównie dzięki samodzielnemu rozumowaniu i rozwiązywania problemów, a nie za pomocą pamięciowego przyswajania wiedzy.

- Aktywność uczniowska ma na celu nie tylko gromadzenie wiedzy czy doświadczeń, lecz także zmianę nastawienia ucznia do uczenia się.

- Uczniowie pracują nad zagadnieniami, które ich interesują i wynikają z ich naturalnych potrzeb. 
- Wprowadzanie rozważań teoretycznych następuje w miarę potrzeb i zawsze wynika z realizowanych działań praktycznych (Stevenson, 1930).

W literaturze rozróżnia się wiele rodzajów projektów. Ze względu na osoby uczestniczące w projekcie możemy wyróżnić projekty indywidualne oraz grupowe; pod względem charakteru pracy nad projektem na: badawcze (gromadzenie informacji o pewnym wycinku rzeczywistości), medialno-artystyczne (tworzenie tekstów literackich, filmów), społeczno-obywatelskie (działania w środowisku lokalnym), które doskonale służą realizacji treści regionalnych. Podczas takich działań buduje się społeczne zaufanie, uczy współpracy pomiędzy uczniami, ale i współdziałania z innymi instytucjami środowiska lokalnego.

Efektywność tej metody zależy od przebiegu kolejnych jej etapów:

1. Przygotowanie projektu:

- Wybór zagadnień do realizacji (nauczyciel może określić w sposób ogólny merytoryczne ramy projektu, może podać pewną pulę szczegółowych tematów lub też ujednolicić pracę grup poprzez podanie wszystkim takiego samego tematu).

- Wstępny opis projektu (opis powinien zawierać: szczegółowy temat projektu, cel projektu oraz przewidywaną formę realizacji i prezentacji).

- Podział uczniów na grupy.

- Określenie standardu efektu końcowego, czyli ustalenie harmonogramu pracy (powinien zawierać następujące elementy: temat projektu i jego cele (opis projektu), formę wykonania projektu (rozwiązania problemu), zadania dla poszczególnych członków grupy, źródła, które powinni wykorzystać, termin prezentacji oraz terminy konsultacji z nauczycielem, możliwe sposoby prezentacji projektu i jej czas, kryteria oceny projektu).

2. Wykonanie projektu:

- Uczniowie realizują działania szczegółowe zgodnie z przyjętym harmonogramem (czynności uczniów dotyczą: zbierania, analizy i selekcji informacji, wykorzystania zdobytej wiedzy w praktycznym działaniu, dokumentowania efektów działań, opracowania sprawozdania, konspektu zajęć).

- Zadania nauczyciela: motywować do samodzielności w działaniach, dokonywać systematycznej obserwacji oceniania postępów w pracach nad projektem, czuwać nad rytmicznością prac, informować o poziomie osiągnięć uczniów oraz własnych oczekiwaniach w celu optymalizacji efektu końcowego projektu).

3. Prezentacja i ocena projektu: 
- Formę prezentacji powinni wybrać sami wykonawcy projektu. Do przykładów takich prezentacji należą: wystawa prac uczniów, album ilustrowany zdjęciami, wykresami, szkicami, mapkami, opracowanie materiałów w formie tekstowej (książka, broszura, ulotka, gazetka), przygotowanie prezentacji multimedialnej, strony internetowej, gry dydaktyczne (inscenizacje, przedstawienia teatralne, edukacyjne gry plenerowe), przygotowanie filmów i nagrań dźwiękowych, pokaz filmu, prezentacja modelu, zorganizowanie seminarium, dyskusji, wywiadów, rozmów itp., raport z przeprowadzonego badania.

- Ocenie podlega szereg elementów projektu: oryginalność i innowacyjność problematyki, zgodność zakresu pracy z założonymi celami, dobór i wykorzystanie różnorodnych źródeł informacji, zawartość merytoryczna pracy, uwzględnienie dodatkowych badań i materiałów, estetyka pracy, terminologia, samodzielność w wykonywaniu projektu, wizualizacja, komunikatywność, zaangażowanie, pomysłowość, przedsiębiorczość (Mikina, Zając 2004; Gołębniak 2002).

\section{WYBRANE ASPEKTY PEDAGOGIKI MIEJSCA JAKO INSPIRACJE DLA EDUKACJI REGIONALNEJ}

\subsection{WARTOŚĆ MIEJSCA W ŚRODOWISKU LOKALNYM - PRZESŁANKI TEORETYCZNE DLA WSPÓŁCZESNEJ SZKOŁY}

O relacji człowieka z miejscem, o jej istotnej roli dla procesów uczenia się i rozwoju człowieka pisała Maria Mendel (Mendel 2017). Podkreślała wagę tworzenia się biografii ludzkich, wspólnot społecznych, kapitału społecznego wynikającego z identyfikacji mieszkańców z zamieszkiwana przestrzenią/miejscem. Miejsca pełnią istotną rolę w edukacji regionalnej, szczególnie użyteczną w środowiskach wielokulturowych, gdzie uczenie o tym, co łączy i o tym, co dzieli, wymaga szczególnych środków przekazu. W analizach miejsca z perspektywy pedagogiki można uwzględnić kilka jego aspektów m.in. lokalizację (location), bowiem miejsce można określić za pomocą obiektywnych współrzędnych na powierzchni ziemi. Miejsca posiadają także materialny kształt (lokale), konkretną formę, układ ulic, placów, pomników, budynków itd. Miejsca można również badać pod kątem znaczenia nadawanego miejscu (sense of place), czyli subiektywny i emocjonalny stosunek człowieka do miejsca (Agnew, 1987; zob. też Lewicka 2012, s. 31). 
Granice środowiska lokalnego wyznaczają miejsca znaczące, mające wartość emocjonalną dla jego mieszkańców. W latach 90. psychologowie środowiskowi (por. Lewicka, 2012, s. 9) poświęcali wiele uwagi badaniom na temat roli, jaką pełni miejsce w tożsamości człowieka, oraz odniesieniom ludzi do miejsc zamieszkania. Pojęcie tożsamości miejsca (place identity) zostało wprowadzone do nauk społecznych przez Harolda Proshansky’ego, pod koniec lat 70., (Proshansky, 1978). Miejsca pełnią ważną funkcję w autoidentyfikacji. Kiedy identyfikujemy się z miejscem, sprawiamy, że stają się one częścią naszej tożsamości. Miejsce w ujęciu Clare Twigger-Ross i Davida Uzzela (Twigger-Ross, Uzzel, 1996, s. 139-169; zob. też: Lewicka, 2012, s. 111), którzy zaadoptowali do badań nad tą kategorią wielowymiarową teorię tożsamości Glynis Breakwell, może stać się częścią tożsamości człowieka, gdy daje mu poczucie ciągłości, pozwala na odróżnienie się od innych, jest źródłem pozytywnej samooceny, a także kiedy daje poczucie skuteczności i kontroli nad otoczeniem.

Miejsca dzięki nadawanym im znaczeniom stanowią ważne kategorie w życiu jednostek. Stają się istotnymi punktami orientacyjnymi w środowisku lokalnym, pomagają odpowiedzieć na jedno z kluczowych pytań tożsamościowych - „skąd pochodzę”. Siła środowiska lokalnego i miejsc znaczących wyznaczających jego granice polega na tym, że jest ono nieodłącznym elementem życia jednostki i grup społecznych. Środowisko lokalne, rozumiane przez T. Pilcha jako:

zbiór ludzi zamieszkujących niewielkie terytorium oraz stworzoną przez nich kulturę, stosunki społeczne i otoczenie przyrodniczo-materialne. Składnikami środowiska lokalnego są wspólne instytucje, symbole i wartości. Cechami tego środowiska są poczucie odrębności i izolacji, jednolitości zawodowej i ekonomicznej, tożsamości etnicznej i kulturowej. Dominacja więzi osobowych nad rzeczowymi pozwala na powszechną identyfikację członków oraz sprawowanie osobowej i rygorystycznej kontroli. Istotą świadomości społecznej środowiska lokalnego jest poczucie jedności wspólnoty i aprobującego uczestnictwa (Pilch, 1999, s. 300),

staje się, doniosłym kontekstem edukacji międzykulturowej. Edukacja międzykulturowa, będąca podstawą edukacji regionalnej, postrzegana przez M. Sobeckiego jako:

wszystkie te oddziaływania, które dotyczą kultur i ich elementów, będących w stanie interakcji (dyfuzji bądź interferencji) oraz zmierzają do takiego kreowania aktów pedagogicznych, że ich efektem jest powstawanie właści- 
wych postaw jednostek i grup wobec odmienności kulturowej oraz świadome, refleksyjne zakorzenienie we własnym dziedzictwie kulturowym (Sobecki, 2007, s. 27),

ma zadanie sprostać wyzwaniom stawianym przez różnorodne społeczeństwo, wykorzystując siłę i potencjał wpisane w miejsca istotne z punktu widzenia tego społeczeństwa.

Thomas Gieryn (Gieryn, 2000, s. 463-496; zob. też Lewicka 2012, s. 10-11) podkreśla różnicę między fenomenem miejsca, które traktuje jako: „punkt we wszechświecie, z nagromadzoną w nim materią staje się miejscem dopiero wtedy, gdy zawiera w sobie historię lub utopię, zagrożenie lub bezpieczeństwo, tożsamość lub pamięć. Miejsce to nie jest po prostu sceneria wydarzeń lub ich tło, ale aktywny gracz w grze - siła, która wywiera dostrzegalny i niezależny wpływ na życie społeczne” (Gieryn, 2000, s. 463-496), a przestrzenią, czyli abstrakcyjnym geograficznym układem. Zgodnie z założeniami edukacji regionalnej podkreśla, że miejsca nie można traktować jak lokalizacji określanej za pomocą kategorii socjologicznych, demograficznych czy ekonomicznych. Zdaniem Gieryna z danych uzyskiwanych z sondaży lub spisów powszechnych również nie zdobędziemy informacji o miejscu. Miejsce nie jest tez nazwą miejscowości, w której badani mieszkają, której używamy do zestawień i porównań statystycznych.

Szczególny udział kategorii miejsca upatruje się w kształtowaniu i przekazie pamięci regionalnej bazującej na pamięci społecznej, rozumianej jako zbiór wspomnień o zdarzeniach rzeczywistych i zmyślonych, miejscach własnych i zdarzeniach, które przeżyło się bezpośrednio, oraz takich, o których wiedza przekazywana jest z pokolenia na pokolenie (por. Szociński, Kwiatkowski, 2006, s. 27). Pamięć społeczna - regionalna - jest wpisana w kategorię ojczyzny prywatnej jako szczególnego miejsca dotyczy tego, co pozostało z przeszłości w przeżyciach członków grupy lub tego, co uczynili, swoją przeszłością. Pamięć społeczna jest kluczowym elementem tożsamości człowieka, to warunek poczucia ciągłości tożsamości grupowej (Sacharczuk, Szwarc, 2018).

\subsection{PRZESZŁOŚĆ GRUP REGIONALNYCH ŹRÓDŁEM WIEDZY O „OJCZYŹNIE PRYWATNEJ" - TYPY PAMIĘCI REGIONALNEJ}

Stanisław Ossowski pisząc o „ojczyźnie prywatnej”, miał na myśli miejsce najbliższe, związane z regionem zamieszkania, oswojone, przesycone indywidualną biografią człowieka, któremu naddawane są osobiste znaczenia emocjonalne (Ossowski, 1967). Ojczyzna prywatna jest miejscem znaczącym, w którym domi- 
nuje stosunek osobisty zachodzący miedzy jednostką a terytorium: „przywiązanie do środowiska, w którym się spędziło życie albo znaczną część życia, czy wreszcie okres szczególnie podatny na tworzenie się trwałych więzi emocjonalnych, przede wszystkim okres dzieciństwa” (Ossowski, 1946, s. 26). Ojczyznę prywatną przeciwstawiał ojczyźnie ideologicznej, o której pisał, to „moja ojczyzna w ideologicznym znaczeni - to ziemia mojego narodu. Istotą mojego związku z tą ziemią, jest uczestnictwo we wspólnocie narodowej” (Ossowski, 1946, s. 26). Pojęcie ojczyzny ideologicznej wiąże się z przekonaniem jednostki o jej uczestnictwie w konkretnej zbiorowości narodowej, która jest związana z pewną szerszą przestrzenią.

Analizując zadania stojące przed edukacją regionalną realizowaną w obszarze pedagogiki miejsca, trzeba zwrócić uwagę na formy lokalnej pamięci. W tym zakresie istotna jest przedstawiona przez A. Szpocińskiego typologizacja odniesień do „małej ojczyzny”, co autor określa pamięcią przeszłości grup lokalnych i regionalnych (Szpociński, Kwiatkowski, 2006, s. 51-63). W działaniach edukacyjnych warto uwzględnić następujące typy lokalnej pamięci przeszłości - typ klasyczny region-naród, który, jak pisze, jest najczęściej kojarzony z przeszłością lokalną. Opisane przez Szpocińskiego zjawisko jest obecne w naszej kulturze od początków XX wieku oraz dobrze rozpoznane w literaturze (Kwiatkowski, 1990).

Jest to pamięć o wydarzeniach, osobach, wytworach kulturowych związanych ze społecznością regionalną, cenionych i upamiętnianych na różne sposoby przede wszystkim dlatego, że reprezentują wartości (idee, wzory zachowań) ważne z punktu widzenia narodu, którego ta społeczność jest członkiem. Nośnik znaczenia zaczerpnięty jest z zasobów kultury lokalnej, natomiast idee, wartości, wzory zachowań z kultury narodowej. W tym typie pamięci zasadniczą funkcją odwołań do przeszłości jest podnoszenie znaczenia społeczności lokalnej w obrębie grupy narodowej. Funkcją takiego rozłożenia elementów składowych pamiętanej przeszłości jest potwierdzenie przynależności społeczności regionalnej do nadrzędnej względem niej społeczności narodowej oraz zgłaszanie i uzasadnianie roszczeń do szacunku dla społeczności lokalnej za jej wkład w kulturę narodową. Odwołania do przeszłości lokalnej podkreślają związki regionu z narodem, a jednocześnie silnie uwydatniają swoistość regionu, nieroztapianą w kulturze narodowej. A. Szpociński na podstawie przeprowadzonych badań Społeczeństwo polskie wobec przeszłości w odniesieniu do klasycznego typu pamięci lokalnej wysnuwa wniosek, że: „przeszłość regionalna jest tym kręgiem pamięci zbiorowej, który budzi najwięcej ciekawości, a zatem powinien w dającej się przewidzieć przyszłości stać się obszarem inwazji zainteresowań choćby niektórych grup społeczeństwa” (Szpociński, Kwiatkowski, 2006, s. 54). Cytowany autor zauważa, że w kulturze społeczeństwa polskiego ubiegłego i obecnego wieku atrakcyjność tego typu pamięci w znacznym 
stopniu zależy od odpowiednich instytucji lokalnych, w tym lokalnej prasy, radia i telewizji oraz stowarzyszeń.

Drugi wyróżniony przez A. Szpocińskiego typ przeszłości regionalnej określony został mianem region-wspólnota ponadnarodowa (Szpociński, Kwiatkowski, 2006, s. 55-57). Ta forma pamięci pojawia się w momencie, gdy związki z centrum państwowym słabną lub gdy obok centralnych instytucji państwowych występują inne centra mające jakieś odniesienia do regionu. W tym wypadku nośnik znaczenia zaczerpnięty jest z zasobów kultury lokalnej a idee, wartości, wzory zachowań z kultury ponadnarodowej - w przypadku Polski najczęściej europejskiej, ale również i światowej. Podstawową funkcją odwołań do przeszłości jest podnoszenie prestiżu społeczności lokalnej w wymiarze ponadnarodowym. Przeszłość lokalna/ regionalna przedstawiana jest jako składowa przeszłości ponadnarodowej. W skład tego typu odniesień do przeszłości wchodzą takie elementy dziedzictwa regionalnego, które mogą pretendować do dziedzictwa kontynentalnego, a nawet globalnego. Badacz zauważył, że odniesienia do przeszłości akcentujące światowy (europejski) charakter regionalnego dziedzictwa pojawiają się wyłącznie w rozgłośniach usytuowanych w silnych, mających własne oblicze ośrodkach kulturalnych, takich jak: Kraków, Poznań, Częstochowa, Białystok, Śląsk. Ten typ odniesień do przeszłości pojawiał się wyłącznie na poziomie nadawców instytucjonalnych, natomiast nie był reprezentowany przez osoby biorące udział w dyskusjach panelowych.

Trzecią formą lokalnej pamięci przeszłości opisaną przez A. Szpocińskiego jest przeszłość jako signum loci - znak miejsca - przedstawiona w dwóch wersjach (Szpociński, Kwiatkowski, 2006, s. 57-61). W tym wypadku zwrot ku przeszłości lokalnej/regionalnej służy jedynie uwypukleniu swoistości regionu bez odnoszenia się do relacji region-wspólnota narodowa czy region-wspólnota ponadnarodowa. Ten typ pojawia się często w programach radiowych i spontanicznych rozmowach. Podstawowym budulcem, z jakiego konstruowana jest ta pamięć, są lokalne tradycje i obyczaje związane z życiem codziennym. Tego rodzaju odniesienia pojawiały się wyłącznie w miastach typowo polskich, takich jak Warszawa czy Poznań. Natomiast były nieobecne w dyskusjach w Gdańsku i Wrocławiu. W ostatnim z wymienianych miast często pojawiały się odwołania do rodzinnych tradycji lwowskich.

W pierwszej z wymienionych wersji signum loci przeszłość regionu postrzegana jest przez pryzmat rodziny. We wszystkich badanych miastach, za wyjątkiem Gdańska i Wrocławia, regionalne tradycje związane z życiem codziennym traktowane są jako uogólnione tradycje rodzinne. Mówienie o tradycjach rodzinnych jest jednoznacznie zdawaniem sprawy z tradycji obowiązujących w regionie. Przemieszanie tych porządków, jak wnioskuje A. Szpociński, pozwala stwierdzić, 
że współcześnie pamięć rodzinna i lokalna zyskują autonomię w stosunku do pamięci narodowej. Wśród przyczyn tej sytuacji za P.T. Kwiatkowskim wymienia wydłużenie się średniej długości życia, popularyzację technik rejestracji otaczającej rzeczywistości, zmianę społecznego rozumienia historii. To wszystko sprawia ważne stają się losy zwyczajnych ludzi. Natomiast jak zauważa w dalszej części „zainteresowanie losami zwykłych »niebohaterskich« rodzin przekłada się na zainteresowanie przeszłością regionu, którego kultura stanowiła podstawową pulę zasobów, z jakich czerpała rodzina. Poznanie przeszłości regionu pozwala lepiej zrekonstruować brakujące elementy historii rodzinnej” (Szpociński, Kwiatkowski, 2006, s. 59). Przy czym podkreśla, że dzieje się tak tylko w przypadku rodzin zasiedziałych, a nie wyrwanych z kultury miejsca.

Druga wersja przeszłości jako signum loci związana ze swoistością regionu dotyczy fasadowego sposobu odnoszenia się do przeszłości lokalnej. Najczęściej przedmiotem tego typu pamięci są zabytki lub znane postacie, które traktowane są jako znaki pozwalające na budowanie unikalnego obrazu miasta czy regionu. Aby ta forma pamięci wykształciła się potrzebny jest specyficzny klimat kulturowy, jak zauważa autor - tego nie obserwuje się po stronie białoruskiej, gdzie Tadeusz Kościuszko i Adam Mickiewicz uznawani są za Białorusinów. W tym typie pamięci kultura nie jest powiązana ze ściśle określoną zbiorowością. Pojmowana jest raczej jako zbiór zasobów, do którego dostęp nie jest limitowany członkostwem w grupie, lecz jedynie kompetencjami. Ten typ odniesień wiąże się z procesami globalizacji, otwartością na przepływ informacji i dóbr. W związku z tym A. Szpociński wnioskuje, że w sytuacji, gdy kultura jest zbiorem dóbr i informacji, z którego dowolnie można korzystać, czyni to jej członków otwartymi na inne kultury, a samą różnorodność wartością szczególnie przez nich cenioną (Szpociński, Kwiatkowski, 2006, s. 61).

Badania pedagogiczne w obszarze edukacji regionalnej są potrzebne między innymi po to, by uniknąć kryzysu, przed którym przestrzega Henryka Kwiatkowska, mówiąc, że „(...) człowiek, który w swej pamięci nie ma miejsc, do których chętnie wraca, chociażby myślą, jest na swój sposób pozbawiony więzi z innymi ludźmi, jest w gruncie rzeczy samotny” (Kwiatkowska 2001, s. 41). W myśl idei edukacji regionalnej poznajemy przeszłość, bowiem chcemy objaśnić tu i teraz istniejącą rzeczywistość, objaśnić lub odrzucić istniejące, uznane w tej rzeczywistości systemy wartości. Odkrywanie miejsc znaczących i pielęgnowanie pamięci o nich, uczenie o przeszłości regionu jest ważne dla budowania spójności naszej tożsamości. 


\section{Bibliografia}

Agnew, J. (1987). Place and politics: The geographical mediation of state and society. Boston: Allen and Unwin.

Chałas, K. (2000). Metoda projektu i jej egzemplifikacja w praktyce. Warszawa: „Nowa Era”.

Chałas, K. (2004). Metoda projektów. W: T. Pilch (red.), Encyklopedia pedagogiczna XXI wieku. t. III. Warszawa: Żak Wydawnictwo Akademickie.

Denek, K. (1997). Wycieczki we współczesnej szkole. Poznań: Eruditus.

Denek, K. (2011). Edukacja pozalekcyjna i pozaszkolna. Poznań: Wydawnictwo Naukowe Wyższej Szkoły Pedagogiki i Administracji im. Mieszka I.

Ministerstwo Edukacji Narodowej, Dziedzictwo kulturowe w regionie. Założenia programowe. (1995). Warszawa: MEN.

Gieryn, T. (2000). A space for place in sociology. Annual Review of Sociology, 26.

Gołębniak, B.D. (red.). (2002). Uczenie metodq projektów. Warszawa: Wydawnictwa Szkolne i Pedagogiczne.

Janowski, I. (2002). Wycieczki szkolne. Kielce: Instytut Geografii Akademii Świętokrzyskiej im. Jana Kochanowskiego.

Kruszewski, K. (2007). Sztuka nauczania. Czynności nauczyciela. Warszawa: Wydawnictwo Naukowe PWN.

Kupisiewicz, Cz. (2002). Dydaktyka ogólna. Warszawa: Oficyna Wydawnicza Graf-Punkt.

Kwiatkowska, H. (2001). Czas. Miejsce. Przestrzeń - zaniedbane kategorie pedagogiczne. W: A. Nalaskowski. K. Rubacha (red.), Pedagogika u progu trzeciego tysiq̨clecia. Toruń: Wydawnictwo Naukowe Uniwersytetu Mikołaja Kopernika.

Kwiatkowski, P.T. (1990). Społeczne ramy tradycji. Warszawa: Instytut Socjologii Uniwersytetu Warszawskiego.

Lewicka, M. (2012). Psychologia miejsca. Warszawa: Wydawnictwo Naukowe SCHOLAR. Mendel, M. (2017). Pedagogika miejsca wspólnego: miasto i szkoła. Gdańsk: Wydawnictwo Naukowe Katedra.

Mikina, A., Zając, B. (2004). Jak wdrażać metodę projektów? Kraków: Oficyna Wydawnicza „Impuls”.

Ministerstwo Edukacji Narodowej o edukacji regionalnej - dziedzictwie kulturowym w regionie. (2000). Warszawa: MEN.

Najwyższa Izba Kontroli. Funkcjonowanie świetlic szkolnych wrzesień 2014 - styczeń 2017. (2017). Warszawa: NIK.

Nawój-Połoczańska, J. (2018). Metoda projektu w doradztwie zawodowym. Warszawa: Difin.

Niemierko, B. (2007). Kształcenie szkolne. Podręcznik skutecznej dydaktyki. Warszawa: Wydawnictwa Akademickie i Profesjonalne.

Nikiktorowicz, J. (2017). Etnopedagogika w kontekście wielokulturowości i ustawicznie kształtującej się tożsamości. Kraków: Oficyna Wydawnicza „Impuls”.

Nikitorowicz, J. (2003). Edukacja międzykulturowa. W: T. Pilch (red.), Encyklopedia pedagogiczna. Warszawa: Żak Wydawnictwo Akademickie.

Nikitorowicz, J. (2009). Edukacja regionalna i międzykulturowa. Warszawa: Wydawnictwa akademickie i Profesjonalne. 
Okoń, W. (2003). Wprowadzenie do dydaktyki ogólnej. Warszawa: Wydawnictwo Akademickie ,Żak”.

Ossowski, S. (1946). Analiza socjologiczna pojęcia ojczyzna. Łódź: Zakłady Graficzne „Książka”.

Ossowski, S. (1967). Z zagadnień psychologii społecznej. Warszawa: Państwowe Wydawnictwo Naukowe.

Pery, A., Kmita, D. (2014). Świetlica - szkolną przestrzenią czasu wolnego. Warszawa: ORE.

Petrykowski, P. (2003). Edukacja regionalna. Problemy podstawowe i otwarte. Toruń: Wydawnictwo Uniwersytetu Mikołaja Kopernika.

Proshansky, H.M. (1978). The city and self-identity. Environment and Behavior, 10.

Rozporządzenie Ministra Edukacji Narodowej z dnia 15 lutego 1999 r. w sprawie podstawy programowej kształcenia ogólnego (Dz.U.1999.14.129).

Sacharczuk, S., Szwarc, A. (2018). Politics of memory and the situation of education before and after Poland regains independence on the example of the city of Białystok - contexts of regional education. Acta Universitatis Nicolai Copernici Pedagogika, XXXV (1).

Sajdak, A. (2008). Edukacja kreatywna. Kraków: Wydawnictwo WAM.

Sobecki, M. (2007). Kultura symboliczna a tożsamość. Studium tożsamości kulturowej Polaków na Grodzieńszczyźnie z perspektywy edukacji międzykulturowej. Białystok: Wydawnictwo „Trans Humana”.

Stevenson, J.A. (1930). Metoda projektu w nauczaniu. Lwów-Warszawa: Książnica Atlas. Synak, B. (2000). Społeczno-kulturowe aspekty edukacji regionalnej. W: K. Marzec-Holka (red.). Społeczeństwo. Demokracja. Edukacja. Nowe wyzwania w pracy socjalnej. Bydgoszcz: Wydawnictwo Akademii Bydgoskiej im. Kazimierza Wielkiego.

Szczepański, M.S. (1995). Ludzie bez ojczyzny prywatnej. W: Wszechnica Górnośląska XI. Edukacja regionalna. Katowice, Opole, Cieszyn: Związek Górnośląski.

Szczepański, M.S. (1999). Edukacja regionalna - w kręgu pojęć podstawowych. W: A. Matczak (red.), Badania nad tożsamościq regionalnq. Stan i potrzeby. Łódź-Ciechanów: Krajowy Ośrodek Dokumentacji Regionalnych Towarzystw Kultury.

Szpociński, A., Kwiatkowski, P.T. (2006). Przeszłość jako przedmiot przekazu. Warszawa: Instytut Studiów Politycznych PAN.

Szwarc, A. (2011). Edukacja międzykulturowa w pozalekcyjnych formach kształcenia komunikat z badań. Pogranicze. Studia społeczne, XVII, s. 188-199.

Szymański, M.S. (2010). O metodzie projektów. Warszawa: Wydawnictwo Akademickie „Żak”.

Twigger-Ross, C., Uzzel, D. (1999). Place and identityprocesses. Journal of Environmental Psychology, 16.

Żelazkiewicz, M. (1980). Skuteczność wychowawcza innowacji w zajęciach pozalekcyjnych. Wrocław: Zakład Narodowy im. Ossolińskich. 